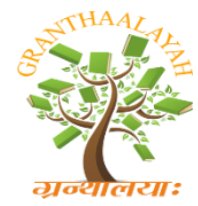

INTERNATIONAL JOURNAL OF RESEARCH GRANTHAALAYAH A knowledge Repository

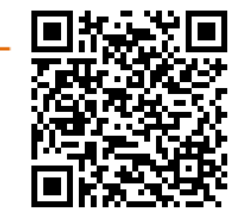

Management

\title{
AN EMPRICAL STUDY ON CONSUMERS ADOPTION OF MOBILE WALLET WITH SPECIAL REFERENCE TO CHENNAI CITY
}

\author{
DR.S.Manikandan ${ }^{* 1}$, J.Mary Jayakodi ${ }^{2}$ \\ ${ }^{* 1}$ Associate Professor, PG and Research Department of Commerce, Gurunanak College, \\ Chennai, India \\ ${ }^{2}$ Research Scholar, Bharathiyar University, India
}

DOI: https://doi.org/10.29121/granthaalayah.v5.i5.2017.1843

\begin{abstract}
In present world smart phones play an important role in the daily life of people. The technological advancement has made smartphone as devices were the mobile users can make money transaction or payment by using application installed in phone. The present study aims to explain the application and usage of wallet money endorsed by different companies and various factors that affect the consumer's decision to adopt mobile wallet and various risks and challenges faced by the users of mobile wallet. A structured questionnaire was prepared and data were collected from 150 respondents and factors affecting the adoption and usage of mobile wallet was analysed by using ANOVA to get the statistical result from data collected.
\end{abstract}

Keywords: Mobile Wallet; Smartphone Users; Mobile Payment.

Cite This Article: DR.S.Manikandan, and J.Mary Jayakodi. (2017). “AN EMPRICAL STUDY ON CONSUMERS ADOPTION OF MOBILE WALLET WITH SPECIAL REFERENCE TO CHENNAI CITY." International Journal of Research - Granthaalayah, 5(5), 107-115. https://doi.org/10.29121/granthaalayah.v5.i5.2017.1843.

\section{Introduction}

The development of technology and technological advancement as made smartphone to become essential part of daily life of people .Smartphone are used as a source of communication device, socialized tool, entertainment, internet and even payment tool. Mobile wallet with the support of mobile technology as allowed the owners of smartphone to carry out many financial transaction and identification implements .The identification implements include name, type and other key words which enhances the security for all the data's on the mobile wallet and these data's are encrypted and lost data's can be recovered by using a backup option.

The mobile wallet money is used in the various areas of the world business like Banks, Customers and Companies. The Banks have taken a better position in providing a better 
transaction services and payment to the customers requirement. For customers are dragged by the shopping facilities that is given by mobile wallet and customers are attracted because of convenience and speedy transaction .In case of companies, the companies aims at providing facility of transaction services and payment choice to their clients and the multiple payment combination facility providing by the company are attached to mobile wallet service .

\section{Review of Literature}

POONAM PAINULY and SHALU RATHI (2016) in their research paper "Mobile wallet :An upcoming mode of business transaction "have analysed that ease of transaction ,secured profile and convenience in handling application put forth the benefits of wallet money and also concluded that business sectors like banking, retail, hospitality etc., are making use of wallet money and mobile payment instruments including contactless and remote payment in the customers -business and customers to customers areas.

RAJESH KRISHNA BALAN, NARAYAN RAMASUBHU, GIRI KUMAR TAYI (2006) in their research paper "Digital wallet: Requirement and challenges "have identified about Singapore's use of digital wallet and analysed the key challenges in building and deploying a digital wallet.

Dr.HEM SHWETA RATHORE in her research paper "Adoption of Digital wallet by consumers "have analysed about the factors that influence consumers in adoption of digital wallet and also analysed the risk and challenges faced by consumers in usage of digital wallet and concluded that shoppers are adopting digital wallet largely due to convenience and ease to use and in the future years digital wallet will gain more widespread acceptance.

\section{Objective of the Study}

1) To study the consumers perception towards mobile wallet.

2) To study the factors that influence consumers in adoption of mobile wallet.

3) To study the problems faced by consumers in use of mobile wallet.

\section{Different Types of E-Wallet}

According to Reserve Bank of India four kinds of wallet money that are available are

\section{Open Wallet}

Open wallet enables the users to buy goods and services, withdraw cash at ATM or bank and transfer funds. M-pesa by Vodafone and ICICI is a good example for open wallet.

\section{Semi-Open Wallet}

Semi -open wallet allows you to transact with merchants that have contract with the companies for e.g. Airtel money is a semi -open wallet were merchants have contract with Airtel in which withdrawal of cash is not possible or can get it back but you can spent the money what you have loaded. 


\section{Closed Wallet}

Closed wallet is a popular with E-commerce were certain amount of money is locked with the merchant in case of cancellation on or return of the order or gift cards .

\section{Semi-Closed Wallet}

A semi-closed wallet allows us to buy goods and services at listed merchant and perform financial services at listed location but a semi-closed wallet does not permit cash withdrawal or redemption for e.g. .PAYTM.

\section{Digital Wallet in India}

\section{- Airtel Money}

With the Airtel Money app, users can easily recharge prepaid accounts or pay postpaid bills. You can also shop online if your digital wallet has cash loaded in it. It's also extremely safe as every transaction or payment you make requires a secret 4-digit mPin.

\section{- Citimasterpass}

Citi MasterPass, a free digital wallet, helps make checking out while online shopping a speedier process. Once you've stored all your payment and shipping details in your Citi Wallet, simply click on the MasterPass button and it will take care of the rest.

\section{- Citrus Pay}

Citrus Pay, one of the top e-wallets in India, it offers a Citrus wallet for customers as well as payment solutions to businesses. With a strong base of 800 million customers, it has definitely earned its spot as one of the best mobile wallets in India.

\section{- Ezetap}

Ezetap, a Bangalore based digital payment solution founded in 2011, offers business owners solutions to accept card payments via electronic devices. It also sends customers e-receipts through an SMS or email.

\section{- Freecharge}

Freecharge, one of the most famous names right now when it comes to digital payment in India, has been known to target the youth in all their promotions. With equivalent amount of coupons given for every recharge you make, it's a great option to save while paying your bills online.

\section{- HDFC PayZapp}

HDFC PayZapp, making digital payment in India simplified with one click payments, is one of the top online wallets in India. Users can easily compare flight and hotel tickets and even buy music or pay bills with the app. Simple connect your debit/credit card once and forget worrying about making payments.

\section{- ICICI Pocket}

While you might find a Pocket card redundant, considering you're opting for an e-wallet app to avoid using a card, they do have a pretty neat wallet app. It's VISA powered and can be used on 
any Indian website, or to transfer money to email ids, WhatsApp contacts, and also just tap and pay your friends easily.

\section{- Jio Money}

JioMoney, launched recently in 2016 by Jio, is a digital payment app. With JioMoney, one can receive great discounts and offers. Users can also bookmark their frequently visited retailers so shopping can be made quicker than usual.

\section{- Juspay}

JusPay Safe is a payment browser with over 650+ transactions in a day. They offer a browser with which users can make payments quickly via cards with 2 clicks.

\section{- Lime}

LIME, launched by AXIS in 2015, was the first mobile app in India to integrate wallets, shopping, payments, and banking. Apart from the usual features like making payments, they also let you analyze what you spend. With a cool feature that rounds up all your change and invest in a deposit, and a shared wallet tool, they've definitely earned their spot in the top list of mobile wallets in India.

\section{- Mobikwik}

Mobikwik is a Gurgaon based e-wallet payment system in India that helps its users store their money. Founded in 2009 by Bipin Singh and Upasana Taku, this digital wallet enables users to recharge, pay bills, and make third-party purchases with one tap.

\section{- Momoexpress}

MomoeXpress, a Bangalore based digital wallet in India, claims to have the fastest checkout system. Though they're only available in Bangalore, they have a wide range of solutions they offer to residents on the city. From paying for your rickshaw ride to salons \& spas, there are over 3000 outlets available at your disposal

\section{- Moneyon Mobile}

MoneyOnMobile, authorized by the Reserve Bank of India, enables users to buy goods, products, and services from registered merchants. It's a multilingual app that reaches remote areas of the country to millions of users making online payments available to a wide population.

\section{- Mswipe}

Mswipe, the first mobile point-of-sales solution in India was founded in 2012. They don't exactly offer an app, but they do provide a machine that can be attached to your mobile device to accept card payments. This may not be a digital wallet app but it does support going cashless.

\section{- Olamoney}

Ola Money, launched in 2015, is a digital wallet in India offered by Ola. While it's majorly being used to make payments for Ola cab rides, making cashless traveling a dream come true, it can also be used to buy groceries or flight tickets and much more. 
- Oxigen

Oxigen, a FinTech company founded in July 2004, is one of the major providers of digital payment in India. Along with making online purchases and paying bills, you can also send gift cards to your dear ones.

- Paymate

PayMate, founded in 2006 by Ajay Adiseshann, launched PayPOS in 2012, an app for small business owners to receive payments conveniently via debit cards and credit cards and also process electronic transactions.

- Paytm

Paytm, launched in 2010, is currently the largest mobile wallet app in India. With payments via Paytm being accepted almost everywhere; it's hard not to simply switch to it completely. From paying mobile bills to buying movie tickets, there's almost nothing you can't do with Paytm.

\section{- Payumoney}

PayUmoney, a part of PayU India, is a free payment gateway solution for merchants to collect payments from customers via debit/credit cards or net banking, and more. They also offer SMS and email invoicing for merchants that do not have a website.

- State Bank Buddy

State Bank Buddy, a product of State Bank of India, is an online wallet in India that's available in 13 languages. Users (non SBI account holders too) can send money via Facebook, or to other bank accounts, book hotels or movie tickets and much more.

\section{Benefits of Mobile Wallet}

The various benefits of mobile wallet are

\section{- Lower Cost}

Purchases made in stores now -a-days does not require cash because purchasing process is been made simple by tapping on the mobile device. The point of sale system as reduced transaction cost of business.

\section{- Competitive Advantage}

Mobile wallet application provides a more comfortable transaction process to the customers giving business that employ this technology a competitive edge in the market

\section{- Modern}

Mobile wallet opens up an entirely new aspect to payment method on large markets, introducing Many businesses opportunities and greater potential revenue.

\section{- Convenience}

Consumers are able to make their purchase in seconds with simply tapping on their mobile device .The purchasing is made quicker and easier bringing satisfaction to the consumers . 


\section{Methodology}

This study is based on primary data collected from 150 respondents in Chennai city by means of structured questionnaire .ANOVA was used to get the statistic result from respondent

\section{Analysis and Interpretation}

Table 1: Demographic Analysis

\begin{tabular}{|l|l|l|l|}
\hline \multicolumn{1}{|c|}{ Basics } & \multicolumn{1}{c|}{ Category } & \multicolumn{1}{c|}{ No of respondents } & Percentage \\
\hline Age & Upton 25years & 45 & 30 \\
\hline \multirow{5}{*}{ Gender } & 26-35years & 40 & 26.67 \\
\cline { 2 - 4 } & $36-45$ years & 35 & 23.33 \\
\cline { 2 - 4 } & 46-55years & 20 & 13.3 \\
\cline { 2 - 4 } & Above 55years & 10 & 6.7 \\
\hline Education & Male & 90 & 60 \\
\cline { 2 - 4 } & Female & 60 & 40 \\
\hline \multirow{5}{*}{ Marital status } & School level & 20 & 13.3 \\
\hline \multirow{5}{*}{ Occupation } & Graduate & 70 & 46.7 \\
\cline { 2 - 4 } & Post graduate & 30 & 20 \\
\cline { 2 - 4 } & Professional & 30 & 20 \\
\cline { 2 - 4 } & Unarried & 90 & 60 \\
\cline { 2 - 4 } & Student & 60 & 40 \\
\cline { 2 - 4 } & Housewife & 15 & 3.3 \\
\cline { 2 - 4 } & Self-employed & 20 & 13.3 \\
\cline { 2 - 4 } & Employed & 100 & 67 \\
\cline { 2 - 4 } & Retired person & 10 & 6.7 \\
\hline \multirow{3}{*}{$\begin{array}{l}\text { Monthly } \\
\text { income }\end{array}$} & Below Rs. 10000 & 20 & 13.3 \\
\hline \multirow{5}{*}{} & & 80 & 13.3 \\
\cline { 2 - 4 } & Rs.10001-20000 & 30 & \\
\cline { 2 - 4 } & Rs.20001-30000 & 30 & 20 \\
\cline { 2 - 4 } & AboveRs. 30000 & 20 & \\
\hline
\end{tabular}

\section{Interpretation}

It is inferred from the table personal information that out of the total respondents taken for the study $30 \%$ of the respondents are in the age group up to 25 years and $26.6 \%$ of the respondents are in the age of $26-35$ years $.60 \%$ of the respondents are male and $40 \%$ of the respondents are female; out of the total respondents $46.7 \%$ of the respondents are graduate and $20 \%$ of the respondents are post graduate. When marital status is concerned $60 \%$ of the respondents are married and $40 \%$ are unmarried and $67 \%$ of the respondents occupational status is employed $.53 .3 \%$ of the respondents belong to the monthly income of Rs.10001-20000 and $13.3 \%$ of them belong to below 10000 as their income level per month. 
Table 2: Data Analysis between Mode of Online Payment and Various Age Groups

\begin{tabular}{|l|l|l|l|l|l|l|}
\hline $\begin{array}{c}\text { Mode of Online } \\
\text { Payment }\end{array}$ & \multicolumn{1}{|c|}{$\begin{array}{c}\text { Sum of } \\
\text { Squares }\end{array}$} & \multicolumn{1}{|c|}{ Df } & $\begin{array}{c}\text { Mean } \\
\text { Square }\end{array}$ & F & Significance \\
\hline Net Banking & BETWEEN GROUP & 1.387 & 4 & .327 & .423 & .798 \\
\hline & WITHIN GROUP & 99.231 & 146 & .773 & & \\
\cline { 2 - 7 } & TOTAL & 100.618 & 150 & & & \\
\hline Mobile Banking & BETWEEN GROUP & 1.657 & 4 & .367 & .196 & .941 \\
\hline & WITHIN GROUP & 252.978 & 146 & 1.990 & & \\
\cline { 2 - 7 } & TOTAL & 254.635 & 150 & & & \\
\hline Mobile Wallet & BETWEEN GROUP & 9.800 & 4 & 2.080 & 2.335 & .065 \\
\hline & WITHIN GROUP & 115.698 & 146 & .978 & & \\
\hline & TOTAL & 125.498 & 150 & & & \\
\hline
\end{tabular}

\section{Interpretation}

Significant level in relation to the online payment and the age group related to mobile wallet is .065 which is above .05and therefore there is no significance difference between the age group and the mode of payment.

Table 3: Data Analysis of Various Factors that Affect the Selection of Mobile Wallet as a Mode of Payment with Reference to Different Age Group

\begin{tabular}{|c|c|c|c|c|c|c|}
\hline $\begin{array}{c}\begin{array}{c}\text { Mode of Online } \\
\text { Payment }\end{array} \\
\end{array}$ & & $\begin{array}{c}\text { Sum of } \\
\text { Squares }\end{array}$ & Df & $\begin{array}{c}\text { Mean } \\
\text { Square }\end{array}$ & $\mathbf{F}$ & Significance \\
\hline \multirow[t]{3}{*}{ Privacy } & BETWEEN GROUP & .456 & 4 & .115 & .790 & .789 \\
\hline & WITHINGROUP & 22.237 & 146 & .151 & & \\
\hline & TOTAL & 22.693 & 150 & & & \\
\hline \multirow[t]{3}{*}{ Security } & BETWEEN GROUP & .645 & 4 & .168 & 1.089 & .410 \\
\hline & WITHINGROUP & 22.456 & 146 & .150 & & \\
\hline & TOTAL & 23.101 & 150 & & & \\
\hline \multirow[t]{3}{*}{ Ease of Use } & BETWEEN GROUP & 2.093 & 4 & .634 & 2.879 & .099 \\
\hline & WITHINGROUP & 40.203 & 146 & .361 & & \\
\hline & TOTAL & 42.116 & 150 & & & \\
\hline \multirow{3}{*}{$\begin{array}{l}\text { Convenience in } \\
\text { Buying Products } \\
\text { Online }\end{array}$} & BETWEEN GROUP & 4.567 & 4 & .988 & 3.890 & .019 \\
\hline & WITHINGROUP & 40.082 & 146 & .268 & & \\
\hline & TOTAL & 44.649 & 150 & & & \\
\hline \multirow{3}{*}{$\begin{array}{l}\text { Pricing (Transaction } \\
\text { Fees, Service Fees) }\end{array}$} & BETWEEN GROUP & 2.761 & 4 & .690 & 1.987 & .170 \\
\hline & WITHINGROUP & 59.625 & 146 & .598 & & \\
\hline & TOTAL & 62.386 & 150 & & & \\
\hline \multirow[t]{3}{*}{ Utility of Innovation } & BETWEEN GROUP & 2.456 & 4 & .654 & 1.764 & .198 \\
\hline & WITHINGROUP & 50.987 & 146 & .403 & & \\
\hline & TOTAL & 53.443 & 150 & & & \\
\hline Usefulness of Digital & BETWEEN GROUP & 3.567 & 4 & .835 & 3.644 & .005 \\
\hline
\end{tabular}




\begin{tabular}{|l|l|l|l|l|l|l|}
\hline \multirow{2}{*}{ Wallet } & WITHINGROUP & 27.138 & 146 & .201 & & \\
\cline { 2 - 7 } & TOTAL & 30.705 & 150 & & & \\
\hline \multirow{3}{*}{ Brand Loyalty } & BETWEEN GROUP & 3.850 & 4 & .956 & 2.895 & .064 \\
\cline { 2 - 8 } & WITHINGROUP & 56.052 & 146 & .405 & & \\
\hline \multirow{2}{*}{ TOTAL } & 59.902 & 150 & & & \\
\cline { 3 - 8 } & & & & & \\
\hline
\end{tabular}

\section{Interpretation}

From the above table it is clear that convenience in buying products online and usefulness of digital wallet is below .05 so it can be concluded that there is statistical difference between age group and mode of payment.

Table 4: Data Analysis on Customers Opinion on Usage of Mobile Wallet

\begin{tabular}{|l|l|l|l|l|l|l|}
\hline & \multicolumn{1}{|c|}{$\begin{array}{c}\text { Sum of } \\
\text { Squares }\end{array}$} & Df & $\begin{array}{c}\text { Mean } \\
\text { Square }\end{array}$ & F & Significance \\
\hline $\begin{array}{l}\text { Mobile Wallet Can } \\
\text { Be an Alternative } \\
\begin{array}{l}\text { Choice of Payment } \\
\text { Mode }\end{array}\end{array}$ & BETWEEN GROUP & 16.068 & 4 & 4.123 & 4.621 & .009 \\
\hline & WITHINGROUP & 135.256 & 146 & .990 & & \\
\cline { 2 - 7 } & TOTAL & & 150 & & & \\
\hline $\begin{array}{l}\text { Mobile Wallet Can } \\
\text { Substitute the Cash } \\
\text { Based Payment } \\
\text { Method }\end{array}$ & BETWEEN GROUP & 4.101 & 4 & .895 & .610 & .789 \\
\hline & WITHINGROUP & 201.985 & 146 & .150 & & \\
\cline { 2 - 8 } & TOTAL & & 150 & & & \\
\hline $\begin{array}{l}\text { Mobile Wallet Can } \\
\text { Support the Existing } \\
\text { Payment Method }\end{array}$ & BETWEEN GROUP & .669 & 4 & .230 & .390 & .890 \\
\hline & WITHINGROUP & 58.968 & 146 & .489 & & \\
\cline { 2 - 8 } & TOTAL & & 150 & & & \\
\hline $\begin{array}{l}\text { Mobile Wallet is Not } \\
\text { Necessary }\end{array}$ & BETWEEN GROUP & .345 & 4 & .080 & .179 & .989 \\
\hline & WITHINGROUP & 59.690 & 146 & .450 & & \\
\cline { 2 - 8 } & TOTAL & 44.649 & 150 & & & \\
\hline
\end{tabular}

\section{Interpretation}

From the table it is mobile wallet can be an alternative choice is below the table value of .05 therefore it is concluded that there is a significant difference in mean between the dependant and independent variable. 


\section{Findings}

- It is clear that mobile wallet will alter the other modes of online payment in future

- The users of mobile wallet are much satisfied on its usage

- Factors like brand loyalty, convenience of shopping plays an important role in adoption of mobile wallet

- Security and safety of funds plays a challenging factor for the users.

\section{Conclusion}

Mobile wallet usage awareness as spread among the people in India due to government policy of demonetization and this as forcefully induced the usage of mobile wallet . The security issues are tighten and risk factors are reduced will automatically increase the adoption of mobile wallet .Apart from these issues the convenience and ease of use as gained an credit to mobile wallet and it can be concluded that they will be a tremendous growth in adoption of mobile wallet in the forthcoming years.

\section{References}

[1] POONAM PAINULY and SHALU RATHI (2016) "Mobile wallet: An upcoming mode of business transactions "International journal in management and social science .volume 4 pp356363.

[2] Dr.HEM SHWETA RATHORE (2016) “Adoption of digital wallet by consumers" BVIMSR's journal of management research. Volume 8 issue 1, pp 69-75.

[3] NGOC DOAN(2014) "Adoption of digital wallet by consumers"www.google.com

[4] AULAKH.,G. (2016). How wallet companies like paytm mobikiwik oxygen wallet are trying to prevent fradulet mobile transactions, retrieved from https://economictimes.indiatimes.com/smallbiz/startups/how-wallet-companies-like-paytm-mobikiwik-oxigen-wallet-are-trying-to-preventfradulet-mobile-transactions/articleshow/50598068.cms

[5] Axis Bank Launches Mobile Wallet to Shop, Pay and Bank (2015, Sept 11) The Business Standard, Retrieved from www.business-standard.com/article/finance/axis-bank-launchesmobile-wallet-to-shop-pay-and-bank-115091101575_1.html.

[6] SINHA.,S.(2015). RBI norms to facilitate E- Commerce, retrieved from https://economictimes.indiatimes.com/news/economy/policy/rbi-norms-to-faclitate-ecommerce/article.show/49102033.cms

[7] KUMAR., A \& SERI., S.P (2014) White paper Banking on the Mobile Wallet - Infosys, Retrieved from https://www.infosys.com/.../white-papers/.../banking-mobile-wallet.pdf Gregory., J. G (2014) Hotels \& Restaurants Dabble in Mobile Payments, Retrived from http://hospitalitytechnology.edgl.com/news/Hotels---Restaurants-Dabble-in-Mobile-

Payment91371 Legas., J (2013) A Study of Mobile Wallet Business Model Development in Sweden, (Master Thesis in Business and Economics) Stockholm School of Economics. Retrieved from arc.hhs.se/download.aspx?MediumId=1959 Graham., F. (2010). GMT M-Pesa: Kenya's mobile wallet revolution

*Corresponding author.

E-mail address: manikandan200922@yahoo.in 